\title{
Evaluation of creatinine as a urine marker and factors affecting urinary excretion of magnesium by dairy cows
}

\author{
A. W. Tebbe and W. P. Weiss ${ }^{1}$ \\ Department of Animal Sciences, Ohio Agricultural Research and Development Center, The Ohio State University, Wooster 44691
}

\begin{abstract}
Nutrient balance studies require measuring urine volume, and urinary excretion can be used to assess $\mathrm{Mg}$ bioavailability. A less laborious method than total collection of urine could make balance studies more feasible and expand the utility of using urinary $\mathrm{Mg}$ as an index of bioavailability, but the method needs to be accurate and sensitive. Sampling interval can affect accuracy because excretion must be at steady state. Two experiments were conducted to (1) determine whether urinary creatinine could be used to accurately estimate urinary output of nutrients markedly excreted via urine $(\mathrm{N}, \mathrm{K}, \mathrm{Na}, \mathrm{S}$, and $\mathrm{Mg}$; experiment 1) and (2) determine the appropriate sampling schedule to evaluate $\mathrm{Mg}$ excretion after abrupt diet changes (experiment 2). Experiment 1 was originally designed to evaluate the interaction of monensin $[0$ vs. $14 \mathrm{mg}$ of monensin/ $\mathrm{kg}$ of dry matter $(\mathrm{DM})]$ and $\mathrm{Mg}$ source ( $\mathrm{MgO}$ vs. $\mathrm{MgSO}_{4}$; total diet $\mathrm{Mg}: 0.36 \%$ of $\mathrm{DM}$ ) under antagonism from increased dietary $\mathrm{K}(2.11 \%$ of $\mathrm{DM})$ on urinary $\mathrm{Mg}$ excretion. Experiment 2 evaluated the interaction of $\mathrm{Mg}$ concentration (basal vs. supplemental $\mathrm{MgO}$; total diet $\mathrm{Mg}: 0.20$ vs. $0.42 \%$ of $\mathrm{DM}$ ) and $\mathrm{K}$ (basal vs. supplemental $\mathrm{K}_{2} \mathrm{CO}_{3}$; total diet $\mathrm{K}$ : 1.60 vs. $2.57 \%$ of $\mathrm{DM}$ ) on urinary $\mathrm{Mg}$ excretion over time. Using 4-d composite samples from total collection of urine ( $\mathrm{n}=34$ cow-periods), the average daily excretion of creatinine was similar to previous estimates (29.0 $\pm 1.16 \mathrm{mg}$ of creatinine $/ \mathrm{kg}$ of body weight) but was variable among cows (root mean squared error $=2,980$ $\mathrm{mg} / \mathrm{d} ; 14 \%$ of mean). Treatment-average estimated excretion of urine and urinary $\mathrm{N}, \mathrm{K}, \mathrm{Na}, \mathrm{S}$, and $\mathrm{Mg}$ were similar to actual values; however, differences between actual and estimated values could be substantial for individual cows. Using the mean creatinine excretion per kilogram of body weight for all cows to estimate urine eliminates the lack of fit variance resulting in artificially low within-treatment variation for estimated urine
\end{abstract}

Received November 6, 2017.

Accepted January 31, 2018.

${ }^{1}$ Corresponding author: weiss.6@osu.edu volume. The standard error of the mean for estimated urine volume was $23 \%$ less (1.93 vs. 2.51) than that for actual urine production. This inflated the type I error rate, and, consequently, statistical inferences on $\mathrm{N}$ and $\mathrm{K}$ excretion differed when urine output was estimated rather than measured. The standard error of the mean for excretion of $\mathrm{Mg}$ calculated with actual or estimated urine production were almost identical (0.92 vs. 0.97); however, similar standard error of the mean was likely caused by differences in the covariance of urinary $\mathrm{Mg}$ concentration with estimated or actual urine output. Based on spot sampling (experiment 2), urinary $\mathrm{Mg}$ reached steady state by $2 \mathrm{~d}$ following an increase in dietary $\mathrm{K}$ regardless of $\mathrm{Mg}$ level, whereas excretion of urinary $\mathrm{Mg}$ following an increase in dietary $\mathrm{Mg}$ continued to increase through $7 \mathrm{~d}$. Estimating nutrient excretion with urinary creatinine and body weight on average is accurate, but variance is likely underestimated. Knowing the time course of urinary $\mathrm{Mg}$ excretion will improve the value of using urinary $\mathrm{Mg}$ concentration to assess diet adequacy or Mg bioavailability.

Key words: magnesium, urinary marker, creatinine, nutrient excretion

\section{INTRODUCTION}

Assessing mineral utilization (Faulkner and Weiss, 2017), environmental impact (de Boer et al., 2002), or dietary requirements (NRC, 2001) often requires measuring nutrient balance in vivo. This involves quantifying urine volume; however, measuring urine volume via total collection is expensive and not feasible under many conditions. Urinary creatinine has been used previously to estimate urine volume and excretion of purine derivatives (Valadares et al., 1999; Chizzotti et al., 2008), but method validity has not been evaluated for elements markedly excreted via urine. For example, 20 to $90 \%$ of the intakes of $\mathrm{N}, \mathrm{Na}, \mathrm{K}, \mathrm{Mg}$, and $\mathrm{S}$ can be excreted in the urine (Tebbe et al., 2018).

Urinary excretion measurements also can be used to estimate relative bioavailability of $\mathrm{Mg}$ (Jesse et al., 1981; Van Ravenswaay et al., 1989, 1992). Under many practical conditions, diets may not provide adequate 
$\mathrm{Mg}$, and deficiencies can develop quickly because lactating dairy cows have only a small reservoir of labile $\mathrm{Mg}$ (Blaxter and McGill, 1956). Several dietary factors alter $\mathrm{Mg}$ absorption, including chemical and physical form of supplemental Mg (Jesse et al., 1981; Van Ravenswaay et al., 1989, 1992), differences within a Mg source (i.e., $\mathrm{MgO}$; Jesse et al., 1981), inclusion of monensin (Greene et al., 1986; Tebbe et al., 2018), and dietary K (Weiss, 2004; Schonewille et al., 2008). A method for quickly evaluating $\mathrm{Mg}$ bioavailability in cows would be useful to ensure a sufficient absorbable supply and quantify factors affecting absorption.

Urinary excretion of $\mathrm{Mg}$ fluctuates over the course of several days after abrupt diet changes (Schonewille et al., 2000), but urinary $\mathrm{Mg}$ concentrations must be at steady state to make accurate comparisons of bioavailability (Van Ravenswaay et al., 1992). Therefore, the main objectives of this study were to (1) evaluate using creatinine for estimating urine output and excretion of major nutrients ( $\mathrm{N}, \mathrm{K}, \mathrm{Na}, \mathrm{S}$, and $\mathrm{Mg}$ ) in lactating dairy cattle and (2) investigate the timeline of urinary $\mathrm{Mg}$ excretion following abrupt dietary changes.

\section{MATERIALS AND METHODS}

\section{Cows and Treatments}

All procedures involving animals were approved by The Ohio State University Institutional Animal Care and Use Committee. Experiment 1 evaluated the use of creatinine as a marker to estimate urine output and urinary excretion of nutrients. The experiment was conducted ancillary to a larger balance study (Tebbe et al., 2018). Briefly, 18 multiparous Holstein cows (139 \pm 35 DIM) were placed into 3 groups of 6 cows. Within each group, 3 cows were randomly assigned to receive no monensin and 3 were fed monensin (Rumensin 90; Elanco Animal Health, Greenfield, IN) at $14 \mathrm{mg} / \mathrm{kg}$ of DM. Cows remained on their monensin treatment for the duration of the experiment (i.e., whole-plot treatment). Within each whole-plot treatment (i.e., split-plot treatment), cows were assigned to 1 of $2 \mathrm{Mg}$ source sequences: (1) MgO (Animag Prilled 30/100; Martin Marietta Magnesia Specialties LLC, Baltimore, $\mathrm{MD}$ ) and then $\mathrm{MgSO}_{4}$ (Magriculture; Giles Chemical, Waynesville, NC) or (2) $\mathrm{MgSO}_{4}$ and then $\mathrm{MgO}$. Periods within a sequence were $21 \mathrm{~d}$, with total collection of feces and urine on d 16 to 20 (Weiss et al., 2009). Based on the time course of $\mathrm{Mg}$ excretion in dry cows (Schonewille et al., 2000), a 16-d diet adaptation period should have been adequate to eliminate carryover effects. Diets were formulated to contain about $40 \%$ $\mathrm{Mg}$ from supplemental $\mathrm{Mg}$ sources and have similar concentrations of total dietary $\mathrm{Mg}$ (target: $0.35 \%$ of
DM; Table 1). The diets were balanced to have similar concentrations of major nutrients and to have elevated $\mathrm{K}$ concentrations (basal diet was $1.3 \% \mathrm{~K}$ plus $0.8 \% \mathrm{~K}$ from $\mathrm{K}_{2} \mathrm{CO}_{3}$ ) to create antagonism on $\mathrm{Mg}$ absorption.

To evaluate the timeline of urinary $\mathrm{Mg}$ excretion following abrupt diet changes, experiment 2 used 32 multiparous Holstein cows ( $215 \pm 32$ DIM) that were placed into 8 blocks of 4 cows based on milk yield (range in average block yields: $20.8-41.8 \mathrm{~kg} / \mathrm{d}$ ). The experiment was conducted in 2 groups of 4 blocks each. Before the experimental period, cows were moved to tiestalls and fed a common diet with typical dietary concentrations of $\mathrm{Mg}$ and $\mathrm{K}$ (0.24 and $1.6 \%$ of DM, respectively). The diet was the same ration the cows had been consuming for several weeks prior. After $7 \mathrm{~d}$ in tiestalls, cows were abruptly changed to 1 of 4 diets (Table 2) for $7 \mathrm{~d}$. Diets were (1) basal (no supplemental $\mathrm{Mg}$ and $\mathrm{K}$; total diet $\mathrm{Mg}$ and $\mathrm{K}: 0.2$ and 1.6\%, respectively); (2) basal $\mathrm{Mg}$, high $\mathrm{K}$ [HiK; total diet $\mathrm{K}: 2.6 \%$ of $\mathrm{DM}, 40 \%$ from $\mathrm{K}_{2} \mathrm{CO}_{3}$ (DCAD Plus; Church \& Dwight Co. Inc., Piscataway, NJ)]; (3) basal $\mathrm{K}$, high $\mathrm{Mg}$ [HiMg; total diet Mg: $0.4 \%$ of DM, $50 \%$ as MgO (Animag Prilled 30/100; Martin Marietta Magnesia Specialties LLC, Baltimore, MD)]; and (4) high $\mathrm{K}$, high $\mathrm{Mg}(\mathbf{H i K}+\mathbf{M g}$; total dietary $\mathrm{K}$ and $\mathrm{Mg}$ : 2.6 and $0.4 \%$ of DM, respectively; $40 \%$ from $\mathrm{K}_{2} \mathrm{CO}_{3}$ and $50 \%$ from $\mathrm{MgO}$ ).

In both experiments, rations were fed once daily with a target refusal rate of $5 \%$. Individual feed delivery and refusal amounts were weighed and recorded daily. Cows were milked twice daily at approximately 0200 and $1400 \mathrm{~h}$, and weights were measured electronically (Afimilk; Kibbutz Afikim, Israel). Body weights were measured on 2 consecutive days at the beginning and end of each experimental period. All $4 \mathrm{BW}$ were then averaged for all calculations.

\section{Samples and Analyses}

Silages and concentrates were sampled once at the end of each experimental period for each group and assayed for DM $\left(100^{\circ} \mathrm{C}\right.$ for $\left.48 \mathrm{~h}\right)$. For other analyses, silages were dried (lyophilized in experiment 1 or $55^{\circ} \mathrm{C}$ for $48 \mathrm{~h}$ in experiment 2) and ground through a 1-mm screen (Wiley mill, Arthur H. Thomas, Philadelphia, PA). Ground silages and concentrate samples were analyzed for DM $\left(100^{\circ} \mathrm{C}\right.$ for $24 \mathrm{~h}$ ), NDF (Ankom Fiber Analyzer, Ankom Technology, Fairport, NY) with sodium sulfite and amylase, $\mathrm{CP}$ (Kjeldahl $\mathrm{N} \times 6.25$; AOAC International, 2000, method 984.13.4.09), and minerals (OARDC Star Laboratory, Wooster, OH) by inductively coupled plasma emission spectroscopy (ICP; Isaac and Johnson, 1985) after microwave digestion in nitric acid (Jones et al., 1991). The analyzed nutrient composition of silages and concentrates was 
used to calculate TMR composition. One refusal sample per cow was collected during each experimental period, analyzed for $\mathrm{DM}\left(100^{\circ} \mathrm{C}\right.$ for $\left.48 \mathrm{~h}\right)$, and used to calculate daily DMI.

In experiment 1, a 4-d composite sample from total collection of urine was used for analysis. To collect urine, external urine cups were attached to the cow's vulva (Weiss et al., 2009). After the urine left the cow, flow was split into 2 streams. One went into a container without acid and was sampled for minerals and creatinine, and the other went into a container with $\mathrm{H}_{2} \mathrm{SO}_{4}$ $(\mathrm{pH}$ of urine $<5)$ and was sampled for $\mathrm{N}$ analysis. For experiment 2, urine was collected from cows via vulva stimulation on the day before treatment diets were fed (d 0) and on d 2, 4, and 7 approximately $5 \mathrm{~h}$ (at $0700 \mathrm{~h}$ ) after feeding. All total collection samples and urine spot samples were assayed for creatinine (creatinine urinary assay no. 500701; Cayman Chemical Co., Ann Arbor, $\mathrm{MI}$ ), $\mathrm{N}$ by the Kjeldahl method (AOAC International, 2000, method 984.13.4.09), and minerals (OARDC
Star Laboratory) by ICP (Isaac and Johnson, 1985) after microwave digestion in nitric acid (Jones et al., 1991). The creatinine intra- and interassay coefficients of variation were 2.4 and $11.1 \%$, respectively. All urine samples from experiments 1 and 2 were also assayed for $\mathrm{Mg}$ using a colorimetric assay (magnesium liquicolor no. 0130; Stanbio Laboratory, Boerne, TX). The colorimetric assay was evaluated because of the lower cost and greater practicality compared with ICP. The Mg colorimetric assay intra- and interassay coefficients of variation were 7.8 and $8.8 \%$, respectively.

During experiment 2, blood was collected from the tail vein into sodium heparin BD Vacutainers (Franklin Lakes, NJ) on d 0,3, and 7 of treatment feeding. Packed cell volume (PCV) was assayed using capillary tubes that were centrifuged (C-MH30; Unico, Dayton, NJ) at room temperature and read with a microcapillary reader (cat. no. 2201; Damon/IEC Division, Needham Heights, MA). Plasma was separated by centrifugation $\left(2,500 \times g\right.$ at $\left.10^{\circ} \mathrm{C}\right)$, frozen, and later analyzed for $\mathrm{Mg}$

Table 1. Ingredient and nutrient composition of $\operatorname{diets}^{1}$ fed in experiment 1 (\% of DM)

\begin{tabular}{|c|c|c|c|c|}
\hline \multirow[b]{2}{*}{ Item } & \multicolumn{2}{|c|}{ Control } & \multicolumn{2}{|c|}{ Monensin } \\
\hline & $\mathrm{MgO}$ & $\mathrm{MgSO}_{4}$ & $\mathrm{MgO}$ & $\mathrm{MgSO}_{4}$ \\
\hline \multicolumn{5}{|l|}{ Ingredient } \\
\hline Corn silage & 34.2 & 34.2 & 34.2 & 34.2 \\
\hline Alfalfa silage & 22.0 & 22.0 & 22.0 & 22.0 \\
\hline Corn grain, ground & 18.4 & 17.5 & 18.4 & 17.5 \\
\hline Soybean meal, $48 \% \mathrm{CP}$ & 12.9 & 13.0 & 12.9 & 13.0 \\
\hline Soy hulls & 8.67 & 7.96 & 8.67 & 7.96 \\
\hline Animal-vegetable fat & 0.49 & 0.48 & 0.49 & 0.48 \\
\hline Potassium carbonate $^{2}$ & 1.51 & 1.49 & 1.51 & 1.49 \\
\hline Dicalcium phosphate & 0.35 & 0.35 & 0.35 & 0.35 \\
\hline Magnesium oxide $^{3}$ & 0.19 & - & 0.19 & - \\
\hline Magnesium sulfate $^{4}$ & - & 1.65 & - & 1.65 \\
\hline Trace-mineralized salt ${ }^{5}$ & 0.70 & 0.70 & 0.70 & 0.70 \\
\hline Mineral-vitamin premix ${ }^{6}$ & 0.62 & 0.62 & 0.62 & 0.62 \\
\hline Monensin ${ }^{7}$ & - & - & 0.007 & 0.007 \\
\hline \multicolumn{5}{|l|}{ Nutrient composition } \\
\hline DM, \% & 59.0 & 58.6 & 59.2 & 58.6 \\
\hline $\mathrm{CP}$ & 17.0 & 16.7 & 16.6 & 16.8 \\
\hline $\mathrm{NDF}$ & 31.6 & 30.8 & 31.8 & 30.9 \\
\hline $\mathrm{Mg}$ & 0.33 & 0.38 & 0.34 & 0.37 \\
\hline $\mathrm{K}$ & 2.12 & 2.09 & 2.12 & 2.11 \\
\hline $\mathrm{Na}$ & 0.26 & 0.29 & 0.24 & 0.27 \\
\hline $\mathrm{S}$ & 0.21 & 0.43 & 0.21 & 0.42 \\
\hline
\end{tabular}

${ }^{1}$ Control $=0 \mathrm{mg} / \mathrm{kg}$ of monensin and $\mathrm{Mg}$ from $\mathrm{MgO}$ or $\mathrm{MgSO}_{4} ;$ monensin $=14 \mathrm{mg} / \mathrm{kg}$ of monensin and $\mathrm{Mg}$ from $\mathrm{MgO}$ or $\mathrm{MgSO}_{4}$.

${ }^{2}$ Contained 56\% K (DCAD Plus; Church \& Dwight Co. Inc., Piscataway, NJ).

${ }^{3}$ Contained 58\% Mg (Animag Prilled 30/100; Martin Marietta Magnesia Specialties LLC, Baltimore, MD).

${ }^{4}$ Contained $9.8 \% \mathrm{Mg}$ (Magriculture; Giles Chemical, Waynesville, NC).

${ }^{5}$ Contained $95 \% \mathrm{NaCl}, 3,500 \mathrm{mg} / \mathrm{kg}$ of Zn, 2,800 mg/kg of Mn, 1,750 mg/kg of Fe, $400 \mathrm{mg} / \mathrm{kg}$ of Cu, $70 \mathrm{mg} /$ $\mathrm{kg}$ of I, $70 \mathrm{mg} / \mathrm{kg}$ of Co (Morton Salt Inc., Chicago, IL).

${ }^{6}$ Contained $60 \mathrm{mg} / \mathrm{kg}$ of Se (sodium selenate), $111 \mathrm{mg} / \mathrm{kg}$ of biotin, $3.8 \mathrm{~g} / \mathrm{kg}$ of Zn (Zinpro 120; Zinpro Corp., Eden Prairie, MN), $0.8 \mathrm{~g} / \mathrm{kg}$ of $\mathrm{Cu}$ (copper sulfate), $500 \mathrm{kIU} / \mathrm{kg}$ of vitamin A, $200 \mathrm{kIU} / \mathrm{kg}$ of vitamin D, and $3,600 \mathrm{IU} / \mathrm{kg}$ of vitamin $\mathrm{E}$.

${ }^{7}$ Contained $198 \mathrm{~g} / \mathrm{kg}$ of monensin (Rumensin 90; Elanco Animal Health, Greenfield, IN). 
(magnesium liquicolor no. 0130). Blood Mg from experiment 1 is reported in Tebbe et al. (2018) and was not affected by treatments.

\section{Calculations and Statistical Analysis}

Two cows during experiment 1 in the $\mathrm{MgO}$ with monensin treatment unknowingly received diets devoid of trace-mineralized salt (apparent by urine $\mathrm{Na}$ excretion $<1 \mathrm{~g} / \mathrm{d}$ and total dietary level $<0.02 \%$ of DM) and subsequently had decreases in DMI and milk yield; all data from these 2 cow-periods were removed.

Daily urinary excretion of creatinine was estimated from total collection samples of experiment $1(\mathrm{n}=34$ cow-periods) and used to calculate creatinine $(\mathrm{mg} / \mathrm{d})$ excreted per kilogram of BW. Urinary creatinine excretion was regressed on average period BW using PROC MIXED (SAS 9.4; SAS Institute, 2015) and adjusted for the random effects of group, cow within a group $\times$ monensin, and period within a group. The fixed effects of treatments (monensin and $\mathrm{Mg}$ source) and their interactions with the independent variable (BW) were tested but were not significant $(P<0.96)$. The intercept was not different from zero $(b=5,741 \mathrm{mg} / \mathrm{d}$; $\mathrm{SE}=6,660 ; P<0.40)$ and was dropped from the model because it lacks biological significance. The slope of the final model $(29.0 \pm 1.16 \mathrm{mg}$ of creatinine $/ \mathrm{kg}$ of BW; $P$ $<0.01$; Figure 1) was the same as a previous estimate (29 mg of creatinine/kg of BW; Valadares et al., 1999) and was used to estimate urine volume and nutrient excretion from all urine spot samples in experiment 2 .

Total collection urinary output and composite samples of experiment 1 were used to evaluate (1) accuracy of estimating urine output using creatinine and BW, (2) analytical method (ICP or colorimetric assay) for measuring urinary $\mathrm{Mg}$ concentration, (3) interaction between analytical method and method of obtaining urinary output on urinary $\mathrm{Mg}$ excretion, and (4) the accuracy of using estimated urine output to estimate excretion of nutrients ( $\mathrm{N}, \mathrm{K}, \mathrm{Na}, \mathrm{S}, \mathrm{Mg})$. The mixed model included the fixed effects of monensin $(1 \mathrm{df}), \mathrm{Mg}$ source (1df), method (1 df for volume, Mg concentration, and nutrient excretion models; 3 df for measuring urinary $\mathrm{Mg}$ output with the 4 methods model), and

Table 2. Ingredient and nutrient composition of $\operatorname{diets}^{1}$ fed in experiment 2 (\% of DM)

\begin{tabular}{|c|c|c|c|c|}
\hline Item & Basal & $\mathrm{HiK}$ & $\mathrm{HiMg}$ & $\mathrm{HiK}+\mathrm{Mg}$ \\
\hline \multicolumn{5}{|l|}{ Ingredient } \\
\hline Corn silage & 40.0 & 40.0 & 40.0 & 40.0 \\
\hline Alfalfa silage & 16.0 & 16.0 & 16.0 & 16.0 \\
\hline Ground corn & 16.2 & 15.8 & 16.2 & 15.9 \\
\hline Soybean meal, $48 \%$ CP & 11.5 & 12.2 & 11.4 & 12.2 \\
\hline Corn gluten feed, dried & 4.54 & 3.77 & 4.45 & 3.65 \\
\hline Soybean hulls & 4.50 & 3.70 & 4.45 & 3.65 \\
\hline Wheat middlings & 4.54 & 3.77 & 4.41 & 3.56 \\
\hline Limestone & 1.00 & 1.00 & 1.00 & 1.00 \\
\hline Animal-vegetable fat & 0.39 & 0.39 & 0.39 & 0.39 \\
\hline Potassium carbonate $^{2}$ & - & 2.00 & - & 2.00 \\
\hline Magnesium oxide $^{3}$ & - & - & 0.36 & 0.36 \\
\hline Trace-mineralized salt ${ }^{4}$ & 0.70 & 0.70 & 0.70 & 0.70 \\
\hline Mineral-vitamin premix ${ }^{5}$ & 0.62 & 0.62 & 0.62 & 0.62 \\
\hline \multicolumn{5}{|l|}{ Nutrient composition } \\
\hline $\mathrm{DM}, \%$ & 57.4 & 57.1 & 57.5 & 56.8 \\
\hline $\mathrm{CP}$ & 14.9 & 15.3 & 15.0 & 15.2 \\
\hline NDF & 35.6 & 34.5 & 35.4 & 34.3 \\
\hline $\mathrm{Mg}$ & 0.20 & 0.18 & 0.42 & 0.43 \\
\hline $\mathrm{K}$ & 1.60 & 2.51 & 1.56 & 2.62 \\
\hline $\mathrm{Na}$ & 0.32 & 0.36 & 0.37 & 0.30 \\
\hline $\mathrm{S}$ & 0.20 & 0.19 & 0.19 & 0.20 \\
\hline
\end{tabular}

${ }^{1}$ Basal = no supplemental $\mathrm{Mg}$ and $\mathrm{K}$ (total diet $\mathrm{Mg}$ and $\mathrm{K}: 0.2$ and $1.6 \%$, respectively); $\mathrm{HiK}=$ supplemental $\mathrm{K}_{2} \mathrm{CO}_{3}$ [total diet $\mathrm{K}: 2.6 \%$ of DM, $40 \%$ from $\mathrm{K}_{2} \mathrm{CO}_{3}$ (DCAD Plus; Church \& Dwight Co. Inc., Piscataway, NJ)]; $\mathrm{HiMg}=$ supplemental $\mathrm{MgO}$ [total diet Mg: 0.4\% of DM, $50 \%$ as MgO (Animag Prilled 30/100; Martin Marietta Magnesia Specialties LLC, Baltimore, MD)], $\mathrm{HiK}+\mathrm{Mg}=$ supplemental $\mathrm{K}_{2} \mathrm{CO}_{3}$ and $\mathrm{MgO}$ (total dietary $\mathrm{K}$ and $\mathrm{Mg}: 2.6$ and $0.4 \%$ of $\mathrm{DM}$, respectively; $40 \%$ from $\mathrm{K}_{2} \mathrm{CO}_{3}$ and $50 \%$ from $\mathrm{MgO}$ ).

${ }^{2}$ Contained $56 \%$ K (DCAD Plus; Church \& Dwight Co. Inc.).

${ }^{3}$ Contained 58\% Mg (Animag Prilled 30/100; Martin Marietta Magnesia Specialties LLC).

${ }^{4}$ Contained $95 \% \mathrm{NaCl}, 3,500 \mathrm{mg} / \mathrm{kg}$ of $\mathrm{Zn}, 2,800 \mathrm{mg} / \mathrm{kg}$ of $\mathrm{Mn}, 1,750 \mathrm{mg} / \mathrm{kg}$ of Fe, $400 \mathrm{mg} / \mathrm{kg} \mathrm{of} \mathrm{Cu}, 70 \mathrm{mg} /$ $\mathrm{kg}$ of I, and $70 \mathrm{mg} / \mathrm{kg}$ of Co (Morton Salt Inc., Chicago, IL).

${ }^{5}$ Contained $54 \mathrm{mg} / \mathrm{kg}$ of Se (sodium selenate), $116 \mathrm{mg} / \mathrm{kg}$ of biotin, $4.0 \mathrm{~g} / \mathrm{kg}$ of Zn (Zinpro 120; Zinpro Corp., Eden Prairie, MN), $1.0 \mathrm{~g} / \mathrm{kg}$ of $\mathrm{Cu}$ (copper sulfate), $590 \mathrm{kIU} / \mathrm{kg}$ of vitamin A, $200 \mathrm{kIU} / \mathrm{kg}$ of vitamin D, and $3,500 \mathrm{IU} / \mathrm{kg}$ of vitamin $\mathrm{E}$. 


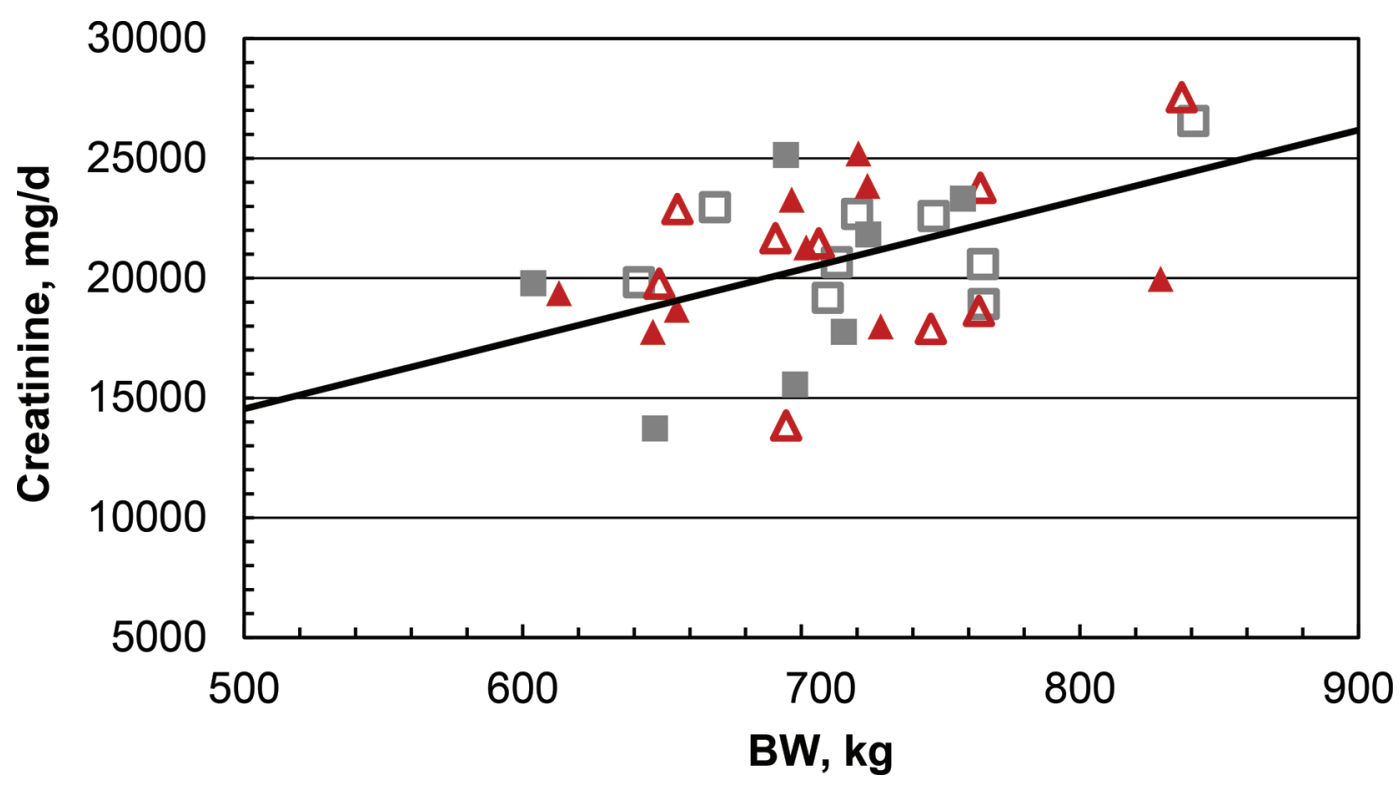

Figure 1. Relationship between BW and creatinine excretion (experiment 1). The Y-intercept was not different than zero $(P>0.40)$ and was removed from the model: $\mathrm{Y}=29.0( \pm 1.16) \mathrm{X}$; root mean squared error $=2,980$. Each symbol represents a cow-period $(\mathrm{n}=34$ cow-periods) from 1 of the 4 dietary treatments and is adjusted for group, cow within a group $\times$ monensin, and period within a group. $\mathrm{MgO}=($ gray $)$ squares; $\mathrm{MgSO}_{4}=(\mathrm{red})$ triangles; no monensin $=$ open shape; monensin $=$ solid shape. Treatment did not affect $(P<0.96)$ the slope. Color version available online.

all 2- and 3-way interactions among fixed effects and the random effects of group, cow within a group $x$ monensin, period within a group, and cow $x$ group $x$ monensin $\times$ period. The different methods of calculating urinary $\mathrm{Mg}$ excretion were compared with output calculated with actual urine production and ICP (i.e., the standard method) using Dunnett's test. Several evaluations were conducted using regression (PROC REG). The root mean squared error (RMSE), which is the square root of the average of squared residuals, was used to evaluate the accuracy of the regressions.

Average milk yield, DMI, and BW of each cow during experimental periods of experiment 2 were analyzed using a mixed model that included the fixed effects of $\mathrm{Mg}(1 \mathrm{df}), \mathrm{K}(1 \mathrm{df})$, and the $\mathrm{Mg} \times \mathrm{K}$ interaction $(1 \mathrm{df})$ and the random effect of block ( $7 \mathrm{df}$ ) and residual error. Blood and urine measures were analyzed with identical models but included the fixed effect of day (repeated) and all 2- and 3-way interactions among other fixed effects. The d 0 plasma $\mathrm{Mg}$ and PCV concentrations differed among treatments and were used as a covariate in their perspective models. The heterogeneous autoregressive covariance structure was used for repeated measures based on the lowest Bayesian information criterion. All degrees of freedom were calculated using the Kenward-Roger method. When time interactions were significant $(P<0.10)$, the SLICE option was used to determine $(P<0.10)$ which days treatment means would be separated using a Fisher least significant difference test.

\section{RESULTS}

The colorimetric method yielded significantly lower urinary $\mathrm{Mg}$ concentrations than did ICP, and the regression had both a mean and slope bias (Figure 2). Perhaps more important, the underestimation caused the statistical interpretation of treatments on urinary $\mathrm{Mg}$ excretion to differ between ICP and colorimetric methods. For example, using ICP data, monensin did not affect urinary $\mathrm{Mg}$ concentration $(P<0.14)$, but with the colorimetric assay, the effect was significant $(P<0.03$; data not shown). Because the regression departed from unity and statistical interpretation of treatment effects differed by analytical method, the succeeding mineral excretion data were from ICPassayed values only.

\section{Experiment 1}

Complete production, digestibility and balance results of experiment 1 were presented previously (Tebbe et al., 2018). Briefly, cows fed $\mathrm{MgSO}_{4}$ consumed about $1.1 \mathrm{~kg} / \mathrm{d}$ less DM $(P<0.01)$, weighed less (711 vs. $722 \mathrm{~kg} ; P<0.03)$, and had a tendency for lower $(P$ $<0.09$ ) milk yields compared with cows fed $\mathrm{MgO}$. 
Feeding $\mathrm{MgSO}_{4}$ with monensin decreased apparent absorption of $\mathrm{Mg}$ compared with diets without monensin (15.6 vs. $19.2 \%$ ), but feeding $\mathrm{MgO}$ with monensin had greater apparent absorption of $\mathrm{Mg}(23.0 \%)$ than other treatments. This monensin $\times \mathrm{Mg}$ interaction paralleled treatment effects on urinary excretion of $\mathrm{Mg}$.

Urine production and nutrient excretion during total collection varied among cow-periods (Table 3). On average, measured urine volume was similar (method: $P<0.96)$ to estimated urine volume (Table 4); however, estimating urine reduced the standard error of the mean about 25\%. When individual cow-period estimates of urine output were compared against actual urine production (Figure 3), the regression had an intercept and slope similar to $0(P<0.15)$ and to $1(P$ $<0.15)$, respectively. The RMSE of the regression was high at $14 \%$ of the mean (RMSE $=4.8$ ), which may have been a reason why no statistical effects on slope and the intercept were observed. Although treatment averages were not statistically different between actual and estimated volume of urine, some individual cow observations differed markedly (Figure 4).

Likewise, treatment-average excretion of $\mathrm{N}$ and minerals $(\mathrm{K}, \mathrm{Na}, \mathrm{S}, \mathrm{Mg})$ did not differ $(P \geq 0.66)$ between urine methods, and no method $\times$ treatment interactions were significant (Table 4). However, statistical
Table 3. Descriptive statistics for measures taken during total collection of urine and feces of experiment 1 ( $\mathrm{n}=34$ cow-period observations from 4 treatments ${ }^{1}$ )

\begin{tabular}{lccc}
\hline & & & \\
Item & Mean & SD & $\begin{array}{c}\text { percentile } \\
\text { perth }\end{array}$ \\
\hline BW, kg & 713 & 58.0 & $644-797$ \\
Milk, kg/d & 40.1 & 6.77 & $32.2-47.4$ \\
Intake & & & \\
DM, kg/d & 25.2 & 1.64 & $23.3-27.3$ \\
Free water, kg/d & 11 & 10.7 & $102-126$ \\
Total water, kg/d & 140 & 11.5 & $127-157$ \\
Urine excretion & & & \\
Volume, kg/d & 33.3 & 6.39 & $25.7-44.8$ \\
Creatinine, g/d & 20.8 & 3.24 & $16.7-25.2$ \\
N, g/d & 215 & 30.7 & $173-253$ \\
K, g/d & 340 & 50.4 & $267-407$ \\
Na, g/d & 39.1 & 10.4 & $25.4-52.6$ \\
S, g/d & 32.0 & 17.7 & $12.1-52.1$ \\
Mg, g/d & 7.9 & 2.38 & $4.7-11.1$ \\
Urinary concentration ${ }^{2}$ & & & \\
Creatinine, mg/L & 634 & 103 & $504-782$ \\
$\mathrm{~N}, \mathrm{~g} / \mathrm{L}$ & 6.54 & 0.74 & $5.60-7.40$ \\
$\mathrm{~K}, \mathrm{~g} / \mathrm{L}$ & 10.3 & 1.01 & $8.46-11.5$ \\
$\mathrm{Na}, \mathrm{g} / \mathrm{L}$ & 1.18 & 0.27 & $0.87-1.59$ \\
$\mathrm{~S}, \mathrm{~g} / \mathrm{L}$ & 1.01 & 0.61 & $0.34-1.73$ \\
$\mathrm{Mg}, \mathrm{mg} / \mathrm{L}$ & 240 & 76.1 & $137-328$ \\
\hline
\end{tabular}

${ }^{1}$ Diets with 0 or $14 \mathrm{mg} / \mathrm{kg}$ of monensin and with $\mathrm{Mg}$ from $\mathrm{MgO}$ or $\mathrm{MgSO}_{4}$.

${ }^{2}$ All values were measured using creatinine colorimetric assay, $\mathrm{N}$ by the Kjeldahl method, minerals with inductively coupled plasma emission spectroscopy, and actual volume.

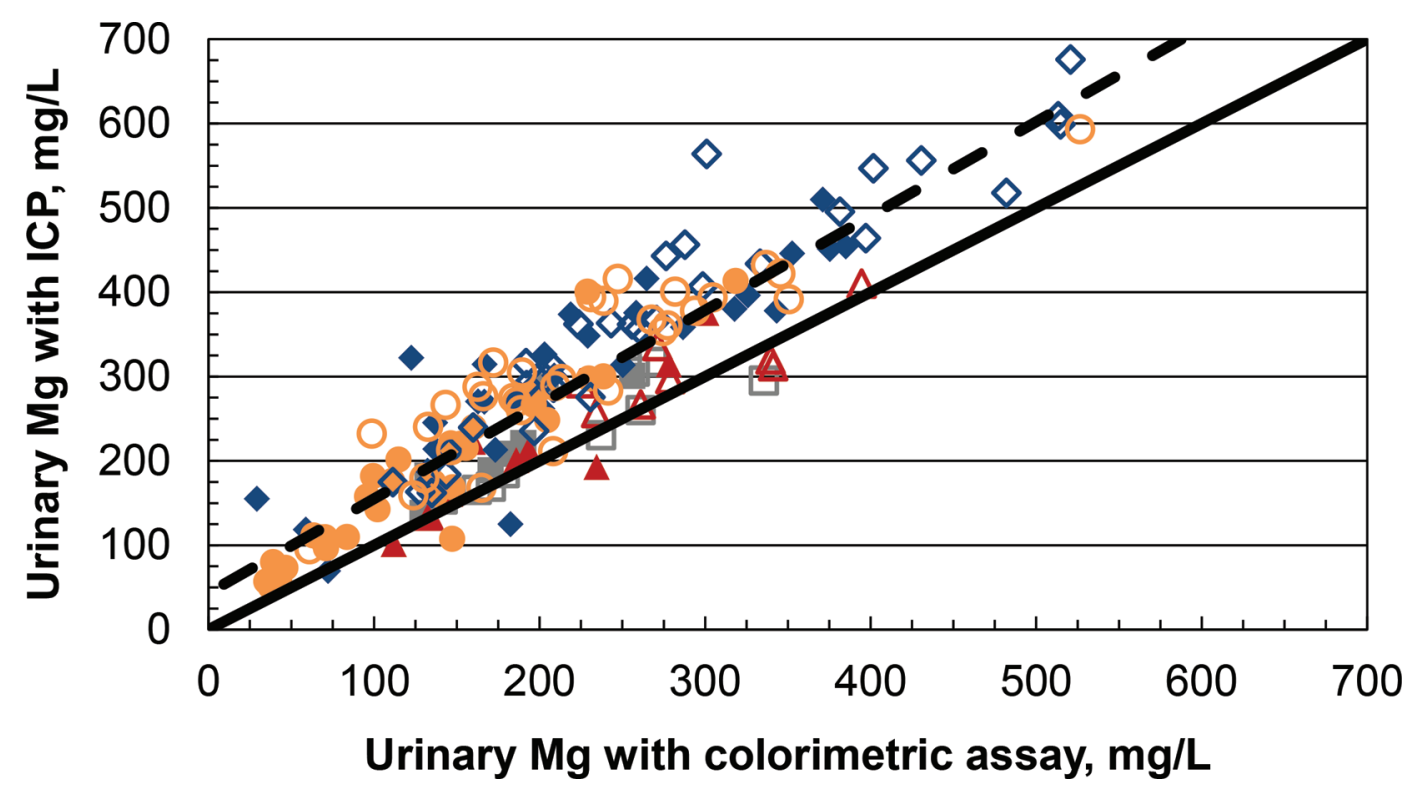

Figure 2. The relationship between $\mathrm{Mg}$ concentration measured using inductively coupled plasma (ICP) emission spectroscopy versus using colorimetric assay: $\mathrm{Y}=1.12( \pm 0.04) \mathrm{X}+43.4( \pm 9.02)$; root mean squared error $=49.8 ; P<0.01$. The Y-intercept and slope were different from $0(P<0.01)$ and $1(P<0.01)$, respectively. The dashed line is the linear regression, and the solid line is $\mathrm{Y}=\mathrm{X}$. Each symbol represents a cow-period $\left(\mathrm{n}=34\right.$ cow-periods) from experiment $1\left[\mathrm{MgO}=\right.$ (gray) squares; $\mathrm{MgSO}_{4}=$ (red) triangles; no monensin $=$ open (gray) shape; monensin $=$ solid $(\mathrm{red})$ shape $]$ and a cow-day $(\mathrm{n}=128)$ experiment 2 [basal $=$ solid (blue) diamonds; HiK $=$ solid $($ orange $)$ circles; HiMg $=$ open (blue) diamond; $\mathrm{HiK}+\mathrm{Mg}=$ open (orange) circle]. Basal = no supplemental $\mathrm{Mg}$ and $\mathrm{K}$ (total diet $\mathrm{Mg}$ and $\mathrm{K}: 0.2$ and $1.6 \%$, respectively); $\mathrm{HiK}=$ supplemental $\mathrm{K}_{2} \mathrm{CO}_{3}$ [total diet $\mathrm{K}: 2.6 \%$ of DM, $40 \%$ from $\mathrm{K}_{2} \mathrm{CO}_{3}$ (DCAD Plus; Church \& Dwight Co. Inc., Piscataway, NJ)]; HiMg = supplemental $\mathrm{MgO}$ [total diet $\mathrm{Mg}$ : $0.4 \%$ of DM, $50 \%$ as $\mathrm{MgO}$ (Animag Prilled 30/100; Martin Marietta Magnesia Specialties LLC, Baltimore, $\mathrm{MD}$ )], $\mathrm{HiK}+\mathrm{Mg}=$ supplemental $\mathrm{K}_{2} \mathrm{CO}_{3}$ and $\mathrm{MgO}$ (total dietary $\mathrm{K}$ and $\mathrm{Mg}: 2.6$ and $0.4 \%$ of $\mathrm{DM}$, respectively; $40 \%$ from $\mathrm{K}_{2} \mathrm{CO}_{3}$ and $50 \%$ from $\mathrm{MgO})$. Color version available online. 
Table 4. Effect of dietary treatment and urine method on nutrient excretion in experiment $1^{1}$

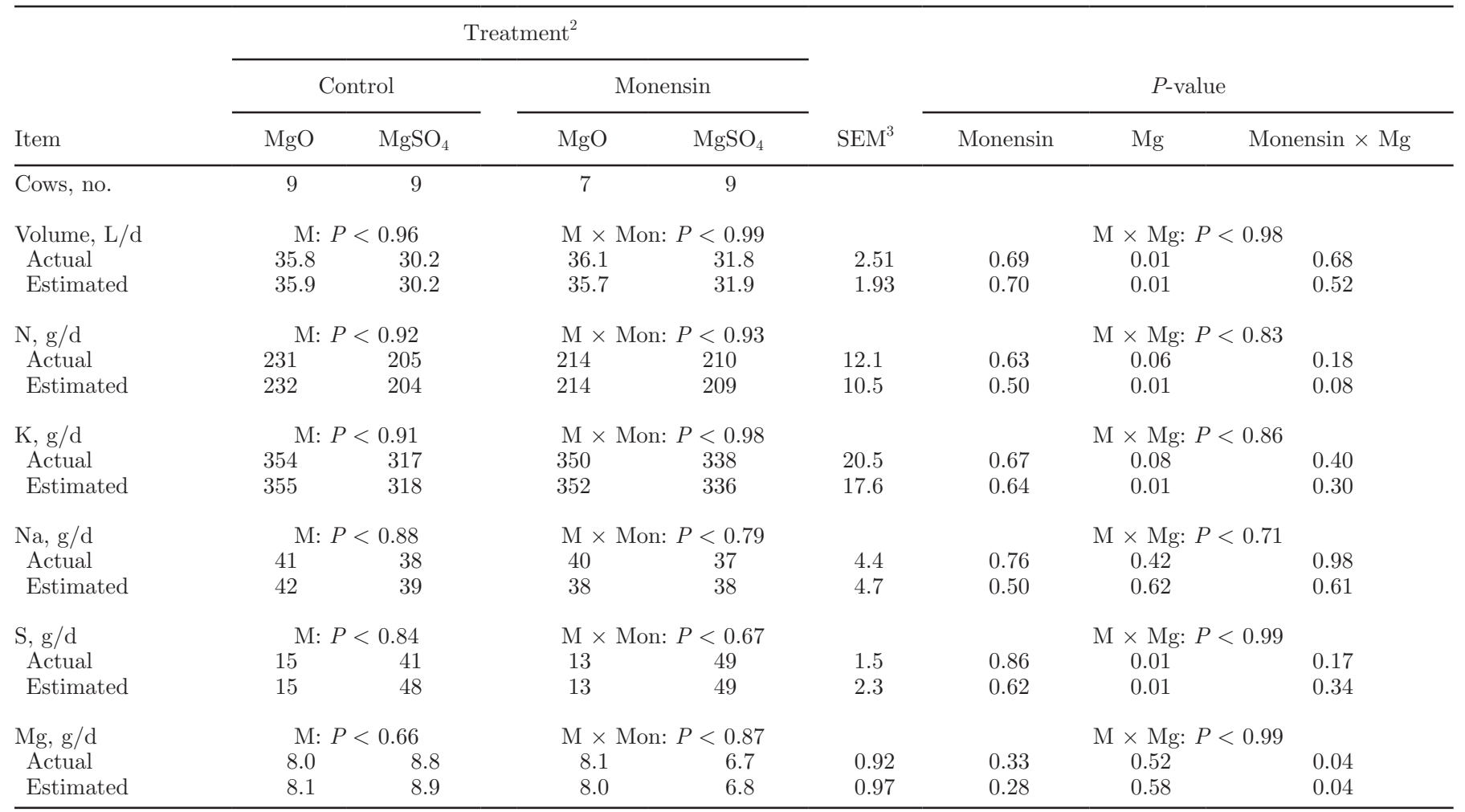

${ }^{1}$ Urine production was either measured from total collection of urine (actual) or estimated from urinary creatinine concentration in a 4-d composite sample (estimated) and BW [volume $=29 \times \mathrm{BW}(\mathrm{kg}) /$ creatinine $(\mathrm{mg} / \mathrm{L})]$. Excretion of nutrients $(\mathrm{g} / \mathrm{d})$ was then calculated using either actual or estimated urine volume. Urinary $\mathrm{N}$ was measured using the Kjeldahl method, and minerals were measured using inductively coupled plasma emission spectroscopy. $\mathrm{M}=$ method; $\mathrm{Mon}=$ monensin.

${ }^{2}$ Control $=0 \mathrm{mg} / \mathrm{kg}$ of monensin and $\mathrm{Mg}$ from $\mathrm{MgO}_{\text {or }} \mathrm{MgSO}_{4}$; monensin $=14 \mathrm{mg} / \mathrm{kg}$ of monensin and $\mathrm{Mg}_{\text {from }} \mathrm{MgO}_{\text {or }} \mathrm{MgSO}_{4}$.

${ }^{3}$ Highest SEM because of unbalanced data.

inferences of treatments changed for $\mathrm{N}$ and $\mathrm{K}$ excretion, likely because the standard error of the mean decreased when estimated urine output was used. The regressions of actual versus estimated excretion of $\mathrm{Mg}$ (Figure 5), $\mathrm{N}, \mathrm{K}$, and $\mathrm{Na}$ departed from unity (Table 5 ). The regression for $\mathrm{S}$ excretion (Figure 6) was the only element that did not differ from unity, but the regression also had the greatest RMSE as a percentage of the mean.

\section{Experiment 2}

Adding supplemental $\mathrm{K}$ or $\mathrm{Mg}$ did not affect DMI, BW, or yield of milk during the 7-d experiment (Table 6 ), but because of the short duration of the experiment, production data may not accurately reflect treatments. Plasma $\mathrm{Mg}$ was greater $(\mathrm{Mg} ; P<0.04)$ for cows receiving supplemental $\mathrm{Mg}$ compared with unsupplemented cows (1.03 vs. $0.99 \mathrm{mM})$. Supplementing K increased $(P<0.01)$ PCV and decreased $(P<0.01)$ urinary creatinine concentrations compared with basal K diets, but no interactions were observed $(P>0.17)$. Esti- mated urine output was about $9 \mathrm{~kg} / \mathrm{d}$ greater for the supplemental $\mathrm{K}$ diets $(P<0.01)$.

Concentration and estimated urinary excretion of $\mathrm{Mg}$ was not different between treatments on d $0(P>0.68)$ and averaged $194 \mathrm{mg} / \mathrm{L}$ and $5.7 \mathrm{~g} / \mathrm{d}$, respectively. Urinary $\mathrm{Mg}$ concentration had $\mathrm{K} \times$ day $(P<0.03)$ and $\mathrm{Mg}$ $\times$ day $(P<0.01)$ interactions, but no 3 -way interaction was observed $(P>0.63$; Figure 7a). When supplemental $\mathrm{Mg}$ was fed concentrations increased over time, whereas concentrations did not change greatly over time for cows fed no supplemental Mg. No discernable pattern is evident describing the $\mathrm{K} \times$ day interaction. Urinary $\mathrm{Mg}$ output (Figure $7 \mathrm{~b}$ ) had a $\mathrm{K} \times \mathrm{Mg}$ interaction $(P<$ $0.10)$. When diets contained supplemental $\mathrm{Mg}$, the addition of $\mathrm{K}$ did not affect urinary $\mathrm{Mg}$ output, but when diets contained no supplemental $\mathrm{Mg}$, the addition of $\mathrm{K}$ decreased urine $\mathrm{Mg}$ output. Supplementing $\mathrm{Mg}$ also interacted with time $(\mathrm{Mg} \times$ day; $P<0.01)$; urinary $\mathrm{Mg}$ output increased over the 7 -d period when cows were fed supplemental $\mathrm{Mg}$ but was essentially unchanged or decreased for cows not fed supplemental Mg. 


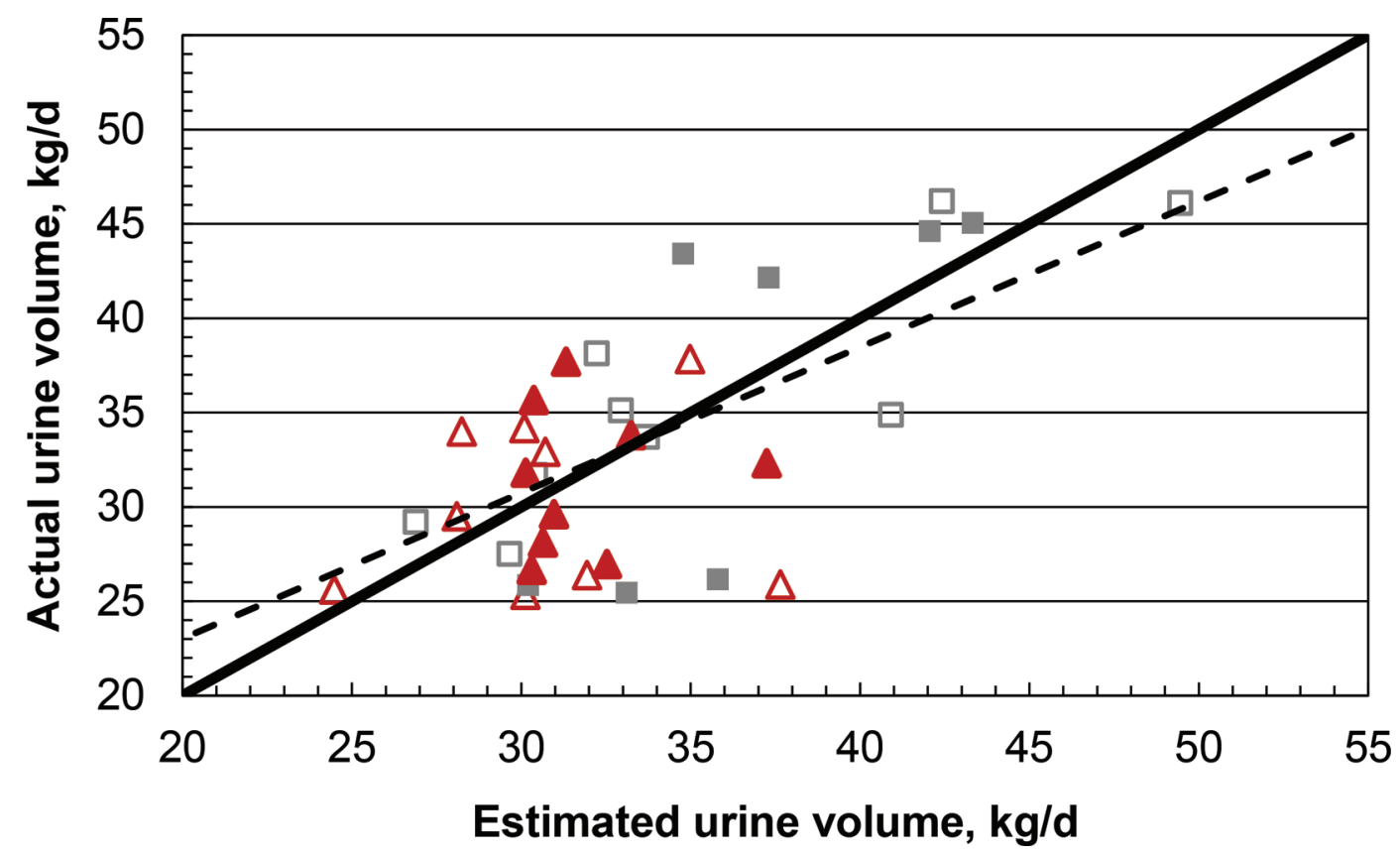

Figure 3. Relationship between actual and estimated urine output using creatinine as a marker (experiment 1$): \mathrm{Y}=0.77( \pm 0.15) \mathrm{X}+7.59$ $( \pm 5.13)$; root mean squared error $=4.8 ; P<0.01$. The Y-intercept and slope were not different from $0(P>0.15)$ and $1(P>0.15)$, respectively. The dashed line is the linear regression, and the solid line is $\mathrm{Y}=\mathrm{X}$. Each symbol represents a cow-period $(\mathrm{n}=34 \mathrm{cow}-\mathrm{periods}) . \mathrm{MgO}=(\mathrm{gray})$ squares; $\mathrm{MgSO}_{4}=$ (red) triangles; no monensin = open shape; monensin = solid shape. Color version available online.

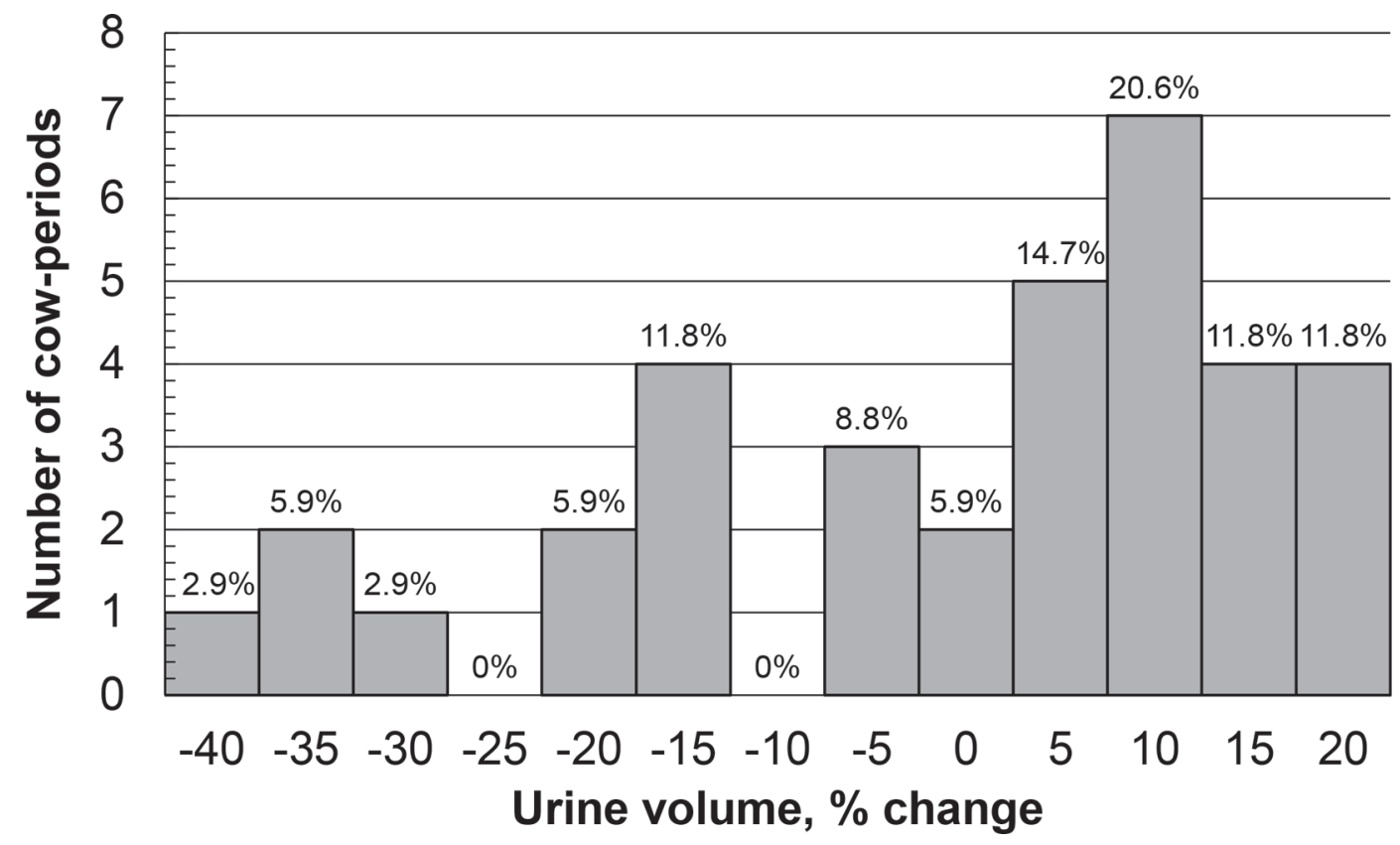

Figure 4. Histogram of deviations between actual and estimated urine output for individual observations: (actual urine volume - estimated urine volume)/actual urine volume $\times 100$ ( $\mathrm{n}=34$ cow-periods). Each bin contains the number of cow-periods within \pm 2.5 percentage units of the value shown on the axis. The percentage of total observations is above each bar. 
Table 5. Actual versus estimated regressions for urine volume and the urinary excretion of nutrients in experiment $1^{1}$

\begin{tabular}{|c|c|c|c|c|c|c|c|c|}
\hline $\begin{array}{l}\text { Dependent variable } \\
\text { (actual) }\end{array}$ & Intercept & $\mathrm{SE}$ & $P$-value ${ }^{2}$ & $\begin{array}{c}\text { Slope } \\
\text { (estimated) }\end{array}$ & $\mathrm{SE}$ & $P$-value ${ }^{3}$ & \multicolumn{2}{|c|}{$\mathrm{RMSE}^{4}$} \\
\hline $\mathrm{N}, \mathrm{g} / \mathrm{d}$ & 121 & 43.5 & 0.01 & 0.44 & 0.20 & 0.01 & 29.1 & 13.5 \\
\hline $\mathrm{K}, \mathrm{g} / \mathrm{d}$ & 181 & 65.5 & 0.01 & 0.47 & 0.19 & 0.01 & 47.0 & 13.8 \\
\hline $\mathrm{Na}, \mathrm{g} / \mathrm{d}$ & 7.3 & 3.85 & 0.07 & 0.81 & 0.09 & 0.05 & 5.84 & 15.0 \\
\hline $\mathrm{S}, \mathrm{g} / \mathrm{d}$ & 2.2 & 2.07 & 0.29 & 0.93 & 0.06 & 0.19 & 5.83 & 18.2 \\
\hline
\end{tabular}

${ }^{1}$ Urine production was either measured from total collection of urine (actual) or estimated from urinary creatinine concentration in a 4-d composite sample (estimated) and BW [volume $=29 \times \mathrm{BW}(\mathrm{kg}) /$ creatinine $(\mathrm{mg} / \mathrm{L})]$. Excretion of nutrients $(\mathrm{g} / \mathrm{d})$ was then calculated using either actual or estimated urine volume. Urinary $\mathrm{N}$ was measured using the Kjeldahl method, and minerals were measured using inductively coupled plasma emission spectroscopy.

${ }^{2} P$-value for rejecting intercept $=0$.

${ }^{3} P$-value for rejecting slope $=1$.

${ }^{4}$ Root mean squared error.

\section{DISCUSSION}

The method of measuring $\mathrm{Mg}$ concentration affected $\mathrm{Mg}$ excretion (Figure 2). The reason for the difference between assay methods is unknown, but the colorimetric assay was developed for measuring $\mathrm{Mg}$ in human urine, which has $\mathrm{Mg}$ concentrations that are approximately 10 to 20 times less than those of the average cow in this study (average: $224 \mathrm{mg} / \mathrm{L}$ ).

Plasma $\mathrm{Mg}$ concentrations did not respond to abrupt diet changes (i.e., no treatment $\times$ day interactions) and did not change when supplemental $\mathrm{K}$ was fed. In contrast, Schonewille et al. (2000) reported a significant decrease in plasma $\mathrm{Mg}$ within $2 \mathrm{~d}$ of feeding additional $\mathrm{K}$. The source of $\mathrm{Mg}$ also did not affect plasma $\mathrm{Mg}$, although apparent absorption differed (experiment 1). Both observations suggest that plasma $\mathrm{Mg}$ is not a sensitive marker of $\mathrm{Mg}$ supply.

Urinary $\mathrm{Mg}$ concentrations were more responsive to dietary changes than blood data; however, if treatment affects urine output, concentration data can be misinterpreted. In experiment 1 , the urine $\mathrm{Mg}$ concentration

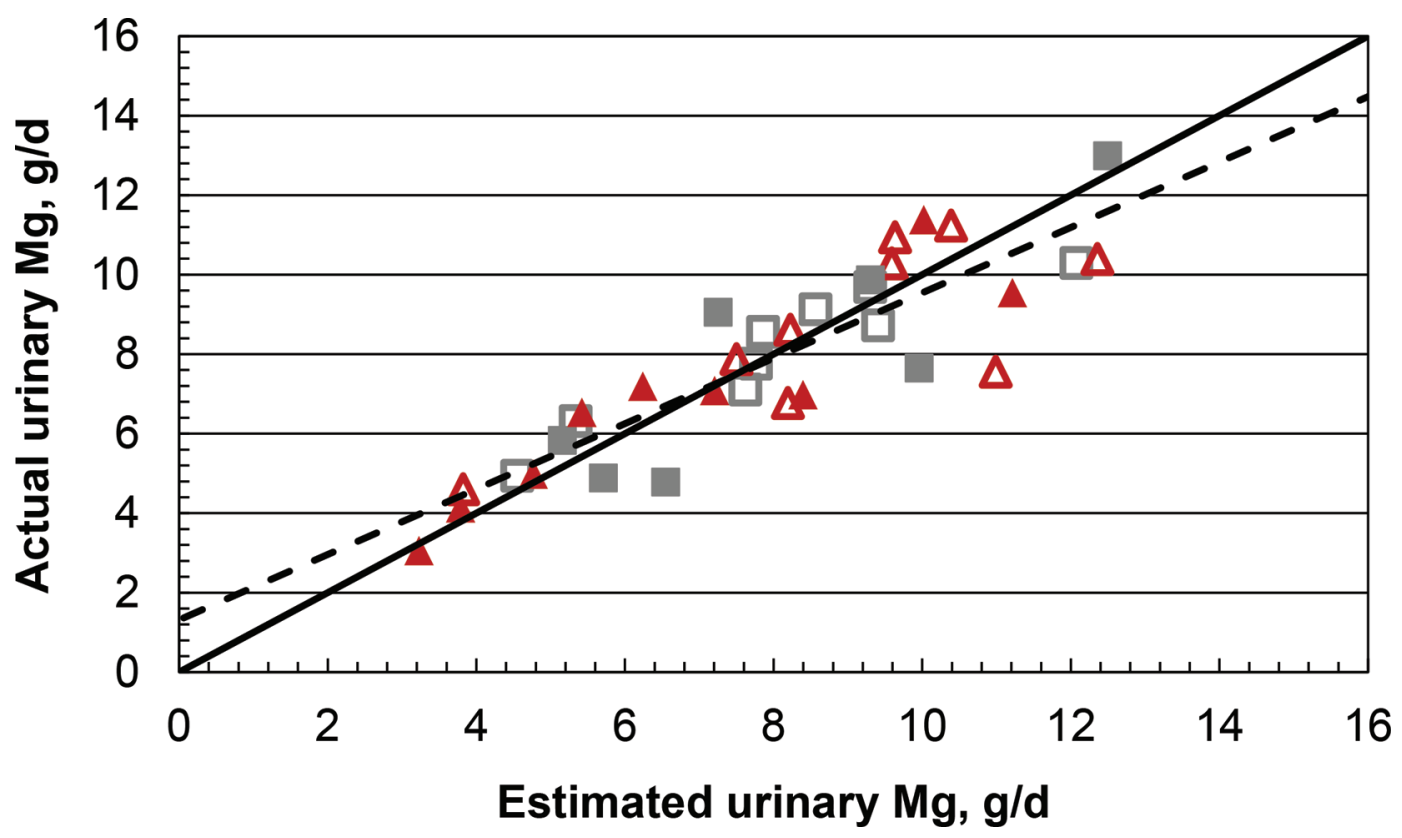

Figure 5. Relationship between urinary Mg excretion determined using actual or estimated (via creatinine) urine output and Mg measured using inductively coupled plasma emission spectroscopy (experiment 1$)$ : $\mathrm{Y}=0.82( \pm 0.08) \mathrm{X}+1.31( \pm 0.66)$; root mean squared error $=1.16$; $P<0.01$. The Y-intercept and slope were different from $0(P<0.05)$ and $1(P<0.03)$, respectively. The dashed line is the linear regression, and the solid line is $\mathrm{Y}=\mathrm{X}$. Each symbol represents a cow-period $(\mathrm{n}=34$ cow-periods $) . \mathrm{MgO}=($ gray $)$ squares; $\mathrm{MgSO}_{4}=(\mathrm{red})$ triangles; no monensin $=$ open shape; monensin $=$ solid shape. Color version available online. 
Table 6. Effect of supplemental $\mathrm{Mg}$ and $\mathrm{K}$ on production measures, blood measures, and urinary excretion (experiment 2)

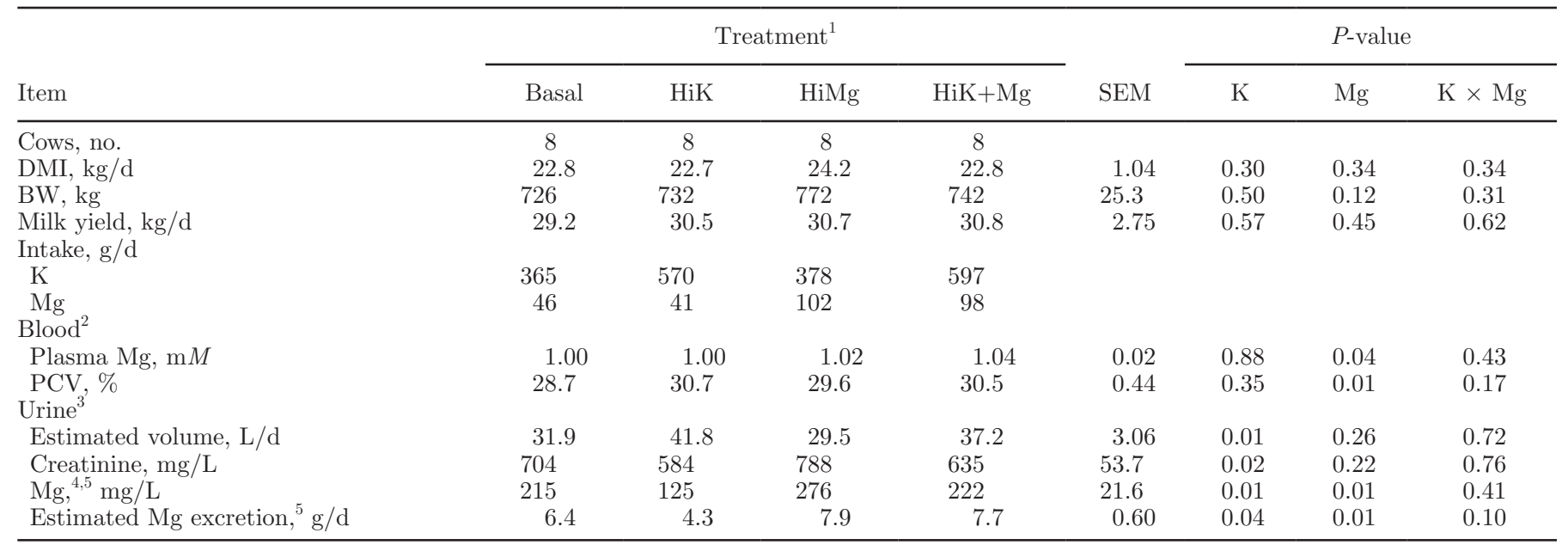

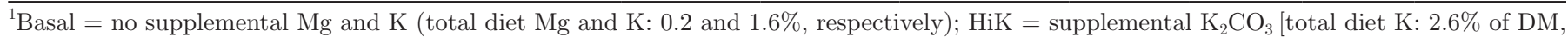
$40 \%$ from $\mathrm{K}_{2} \mathrm{CO}_{3}$ (DCAD Plus; Church \& Dwight Co. Inc., Piscataway, NJ)]; HiMg = supplemental $\mathrm{MgO}$ [total diet $\mathrm{Mg}$ : $0.4 \%$ of DM, $50 \%$ as $\mathrm{MgO}$ (Animag Prilled 30/100; Martin Marietta Magnesia Specialties LLC, Baltimore, MD)], HiK+ $\mathrm{Mg}=$ supplemental $\mathrm{K}_{2} \mathrm{CO}_{3}$ and $\mathrm{MgO}($ total dietary $\mathrm{K}$ and $\mathrm{Mg}: 2.6$ and $0.4 \%$ of $\mathrm{DM}$, respectively; $40 \%$ from $\mathrm{K}_{2} \mathrm{CO}_{3}$ and $50 \%$ from $\mathrm{MgO}$ ).

${ }^{2}$ Plasma $\mathrm{Mg}$ and packed cell volume (PCV) are covariate adjusted means of blood draw on d 3 and 7 . Day was significant (average concentration on d 0,3 , and 7 was 1.01, 1.03, and $0.99 \mathrm{~m} M$, respectively; $P=0.03)$, but no interactions of fixed effects and day were found $(P>0.15)$.

${ }^{3}$ Means of urine spot samples from d $0,2,4$, and 7 . Urine $\mathrm{Mg}$ concentration was measured using inductively coupled plasma emission spectroscopy, and urine volume $(\mathrm{L} / \mathrm{d})$ was estimated $[29 \times \mathrm{BW}(\mathrm{kg}) /$ urinary creatinine concentration $(\mathrm{mg} / \mathrm{L})]$ for measuring $\mathrm{Mg}$ excretion $(\mathrm{g} / \mathrm{d})$.

${ }^{4} \mathrm{~K} \times$ day interaction $(P<0.10)$.

${ }^{5} \mathrm{Mg} \times$ day interaction $(P<0.10)$.

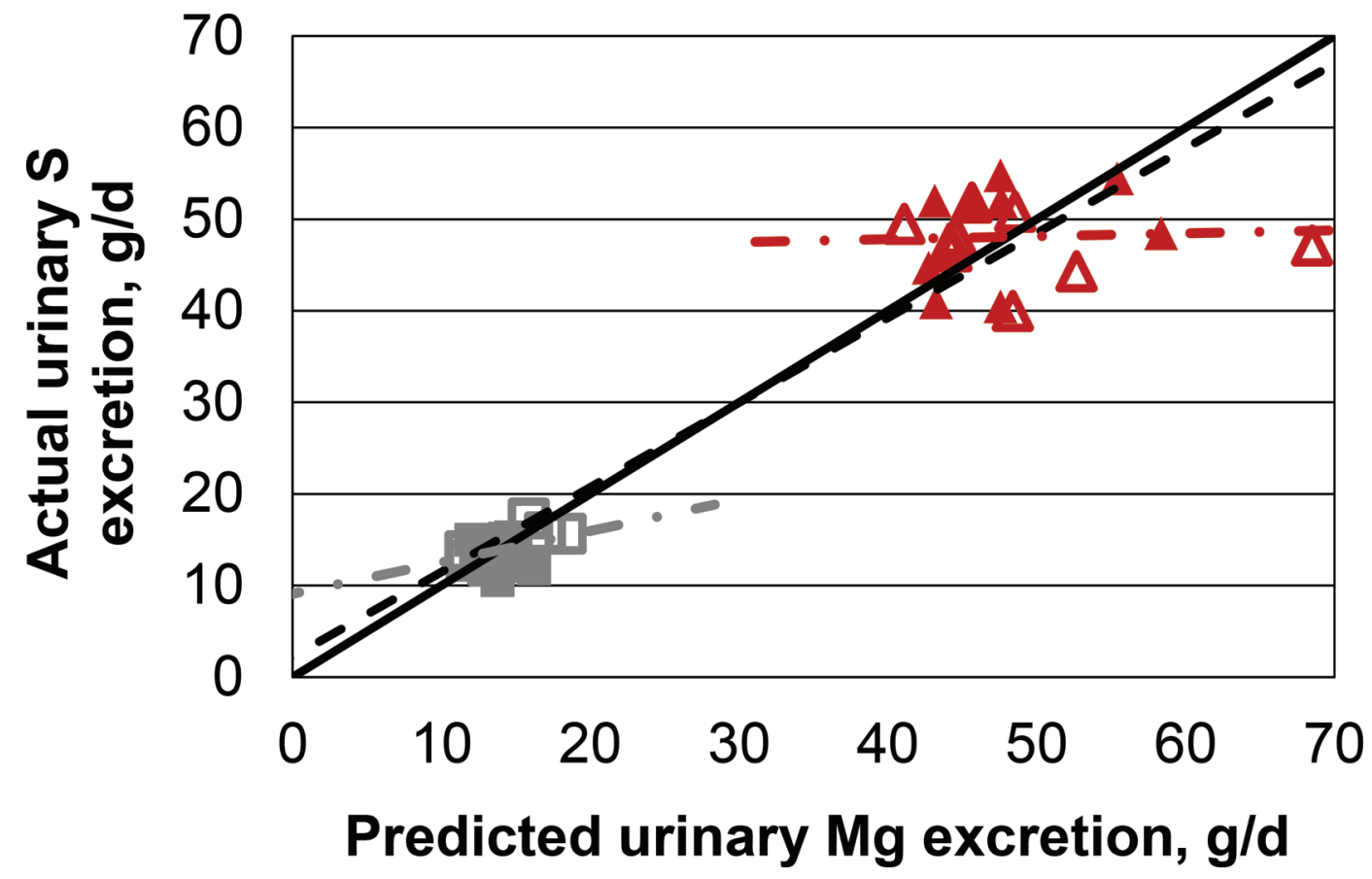

Figure 6. Relationship between urinary S excretion determined using actual or estimated (via creatinine) urine output and $\mathrm{Mg}$ measured using inductively coupled plasma emission spectroscopy (experiment 1$)$ : $\mathrm{Y}=0.93( \pm 0.06) \mathrm{X}+2.2( \pm 2.07)$; root mean squared error $=5.83$; $P<0.01$. The Y-intercept and slope were similar to $0(P<0.29)$ and $1(P<0.19)$, respectively. The dashed line is the linear regression of all cow-periods, the solid line is $\mathrm{Y}=\mathrm{X}$, and the dot-dashed lines are regressions for each source $\left(\mathrm{MgO}=\right.$ gray, line on the left; $\mathrm{MgSO}_{4}=\mathrm{red}$, line on the right). For $\mathrm{MgO}$ treatment (or $0.2 \% \mathrm{~S}$ ), the slope was $0.34\left(\mathrm{SE}=0.22 ; P<0.15\right.$ ), and for the $\mathrm{MgSO}_{4}$ treatment $(0.4 \% \mathrm{~S})$, the slope was 0.03 (SE $=0.17 ; P<0.85)$. Each symbol represents a cow-period $\left(\mathrm{n}=34\right.$ cow-periods). $\mathrm{MgO}=\left(\right.$ gray) squares; $\mathrm{MgSO}_{4}=(\mathrm{red})$ triangles; no monensin $=$ open shape; monensin $=$ solid shape. Color version available online. 
data indicated the $\mathrm{MgSO}_{4}$ treatment without monensin had about $30 \%$ greater $\mathrm{Mg}$ absorption than other treatments (288 vs. $218 \mathrm{mg} / \mathrm{L}$ ); however, this diet had statistically similar urinary $\mathrm{Mg}$ output as the $\mathrm{MgO}$ diets because $\mathrm{Mg}$ source affected urine volume. Expressing $\mathrm{Mg}$ output as a ratio of $\mathrm{Mg}$ to creatinine is also inappropriate because creatinine excretion is proportional to body mass (Schroeder et al., 1990), which inherently varies between cows. Therefore, determining $\mathrm{Mg}$ status or evaluating bioavailability requires measuring or estimating urine volume.

\section{Method of Evaluating Urinary Excretion}

Measuring BW and creatinine to estimate urine output accurately estimated treatment-average urinary output of all nutrients evaluated ( $\mathrm{N}, \mathrm{K}, \mathrm{Na}, \mathrm{S}, \mathrm{Mg}$ ). Our calculated creatinine excretion $(\mathrm{mg} / \mathrm{kg}$ of BW) was identical to a previous estimate for lactating Holsteins (Figure 1; Valadares et al., 1999); however, the lack of fit was high (RMSE $=2,980 ; 14 \%$ of mean; Figure 3), indicating that the rate of creatinine excretion per unit of BW varies considerably among cows. When a con-
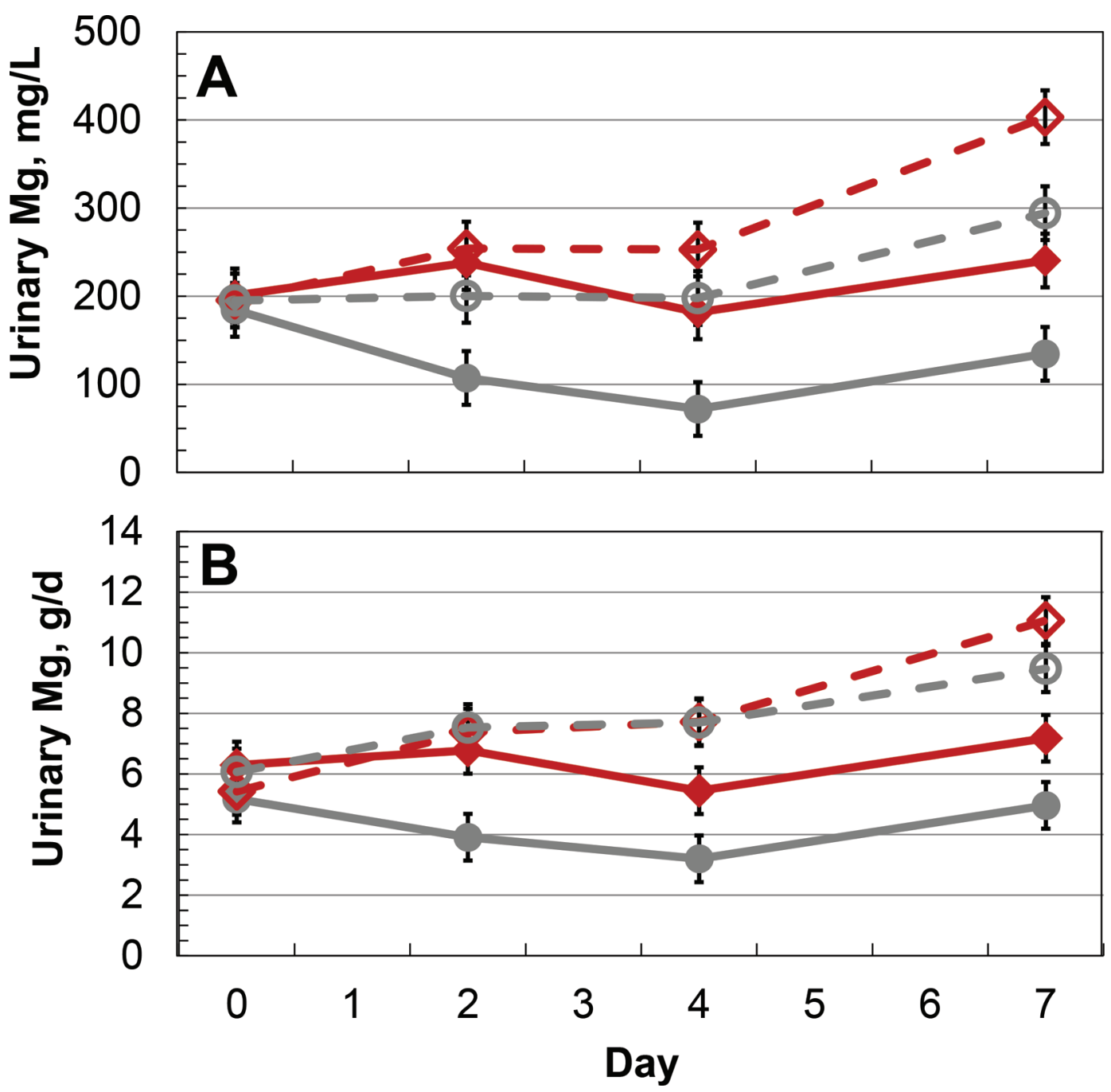

Figure 7. Effect of day after an abrupt diet change (experiment 2) on urinary $\mathrm{Mg}$ (A) concentration $(\mathrm{K} \times$ day, $P<0.03 ; \mathrm{Mg} \times$ day, $P<$ $0.01 ; \mathrm{K} \times \mathrm{Mg} \times$ day, $P<0.63)$ and $(\mathrm{B})$ estimated excretion $(\mathrm{K} \times$ day, $P<0.22 ; \mathrm{Mg} \times$ day, $P<0.01 ; \mathrm{K} \times \mathrm{Mg} \times$ day, $P<0.50)$. Cows were fed diets varying in $\mathrm{Mg}(0.20$ vs. $0.42 \%$ of $\mathrm{DM})$ and $\mathrm{K}(1.60$ vs. $2.57 \%$ of $\mathrm{DM})$. Urine $\mathrm{Mg}$ output was estimated using spot samples and measuring creatinine and $\mathrm{Mg}$ concentration with inductively coupled plasma emission spectroscopy. Bars are the SEM across treatments and days (panel A: SEM $=30 \mathrm{mg} / \mathrm{L}$; panel B: SEM $=0.77 \mathrm{~g} / \mathrm{d}$ ), and each symbol represents the treatment average $\times$ day. Basal $=$ solid $(\mathrm{red})$ diamonds; HiK $=$ solid (gray) circles; HiMg = open (red) diamonds; $\mathrm{HiK}+\mathrm{Mg}=$ open (gray) circles. Basal = no supplemental $\mathrm{Mg}$ and $\mathrm{K}$ (total diet $\mathrm{Mg}$ and $\mathrm{K}$ : 0.2 and $1.6 \%$, respectively); $\mathrm{HiK}=$ supplemental $\mathrm{K}_{2} \mathrm{CO}_{3}$ [total diet $\mathrm{K}: 2.6 \%$ of DM, $40 \%$ from $\mathrm{K}_{2} \mathrm{CO}_{3}$ (DCAD Plus; Church \& Dwight Co. Inc., Piscataway, $\mathrm{NJ}$ )]; HiMg = supplemental $\mathrm{MgO}$ [total diet Mg: 0.4\% of DM, 50\% as MgO (Animag Prilled 30/100; Martin Marietta Magnesia Specialties LLC, Baltimore, MD)], $\mathrm{HiK}+\mathrm{Mg}=$ supplemental $\mathrm{K}_{2} \mathrm{CO}_{3}$ and $\mathrm{MgO}$ (total dietary $\mathrm{K}$ and $\mathrm{Mg}: 2.6$ and $0.4 \%$ of $\mathrm{DM}$, respectively; $40 \%$ from $\mathrm{K}_{2} \mathrm{CO}_{3}$ and $50 \%$ from $\mathrm{MgO}$ ). Color version available online. 
stant rate is assumed for urine volume calculations, that variation was ignored and resulted in an artificially low standard error of the mean for estimated excretion of urine, $\mathrm{N}$, and $\mathrm{K}$ compared with measured urine outputs (Table 4). Inaccurate error variance for estimated urine output inflated the Type I error rate (i.e., increased probability of incorrectly rejecting null hypothesis) and produced several incorrect statistical inferences (i.e., N and $\mathrm{K}$ excretion). The lack of fit was apparent even though the samples came from total output of urine over a 4-d period. Studies that spot sample urine may introduce more variation than we observed because of diurnal variation (Shingfield and Offer, 1998). Day-today variation in urine volume, which averaged about $16 \%$ during total collection (data not shown), could also affect accuracy and precision of spot sampling if samples are not taken over enough days.

Disregarding lack of fit variation in creatinine excretion rate did not reduce the standard error of the mean of all excretion estimates (i.e., $\mathrm{Na}, \mathrm{S}$, and $\mathrm{Mg}$; Table 4). Upon further investigation, urinary concentration of $\mathrm{Na}$ and $\mathrm{Mg}$ was more negatively correlated with actual urine volume than with estimated volume (Mg: $\mathrm{r}=-0.32$ vs. $-0.16 ; \mathrm{Na}: \mathrm{r}=-0.13$ vs. -0.04$)$. This means that variation in actual urine excretion of those nutrients was reduced as urine volume increased, but not so with estimated urine output. The reason for the different correlations is unknown, but if real, it may increase differences between actual and estimated output at either low or high excretion rates of urine. Although regression analysis indicated that estimated excretion of $\mathrm{S}$ was accurate, the regression analysis must be evaluated carefully (Figure 6). By design, concentration of dietary $\mathrm{S}$ differed between $\mathrm{Mg}$ source treatments (0.2 vs. $0.4 \%)$, and when regressions were performed within each $\mathrm{Mg}$ treatment, the slope relating estimated to actual urinary excretion of $\mathrm{S}$ was not significant. For $\mathrm{MgO}$ treatment (or $0.2 \% \mathrm{~S}$ ), the slope was 0.34 ( $\mathrm{SE}=$ $0.22 ; P<0.15)$, and for the $\mathrm{MgSO}_{4}$ treatment $(0.4 \%$ $\mathrm{S})$, the slope was $0.03(\mathrm{SE}=0.17 ; P<0.85)$. This suggests that if dietary $\mathrm{S}$ does not vary greatly among diets, estimating excretion with creatinine may not be accurate.

Variable rates of creatinine excretion per kilogram of BW also caused individual cow urine output to differ substantially from estimated output (Figure 4). Estimated urine volume differed from actual urine output by more than $15 \%$ in 13 of the 34 cow-periods (38\% of observations) and by more than $20 \%$ in $15 \%$ of the observations. These large differences indicate that an adequate number of cows is needed to obtain accurate results; however, we cannot determine the number needed from this experiment.

\section{Time Course of Mg Excretion}

For valid comparisons, $\mathrm{Mg}$ urinary excretion must be at steady state (Van Ravenswaay et al., 1992). For diets with supplemental $\mathrm{K}$ (i.e., $\mathrm{HiK}$ and $\mathrm{HiK}+\mathrm{Mg}$ ), the decrease in estimated $\mathrm{Mg}$ output was stable by $\mathrm{d} 2$ (Figure 7b). In dry cows abruptly switched to a high-K diet (2.6-5.0\% of $\mathrm{DM})$, urinary $\mathrm{Mg}$ excretion required 4 to $6 \mathrm{~d}$ to stabilize (Schonewille et al., 2000). Absorption of $\mathrm{Mg}$ occurs in the rumen, and because $\mathrm{K}_{2} \mathrm{CO}_{3}$ is rapidly solubilized in the rumen, the antagonistic effect of $\mathrm{K}$ on $\mathrm{Mg}$ absorption should develop quickly upon increased K intakes. Faster time to steady state in lactating cows is likely a consequence of higher Mg demand and faster depletion of blood $\mathrm{Mg}$ compared with dry cows. Based on the NRC (2001) Mg requirement, a nonpregnant, nonlactating cow weighing the same as the average lactating cow of experiment 2 (Table 6) requires about 3 -fold less $\mathrm{Mg}(2.1$ vs. $6.1 \mathrm{~g} / \mathrm{d}$ ) than the average cow in this experiment. Because healthy cows may have only 3 to $4 \mathrm{~g}$ of labile $\mathrm{Mg}$ (Storry, 1961; Fach, 2015), urinary homeostasis (and hypomagnesemia) likely occurs more quickly for lactating cows after abrupt increases in dietary $\mathrm{K}$.

When dietary $\mathrm{Mg}$ intake was doubled (HiMg and $\mathrm{HiK}+\mathrm{Mg}$ diets), urinary output of $\mathrm{Mg}$ did not appear to reach steady state by $d 7$. In sheep, urinary excretion of $\mathrm{Mg}$ was consistently stable 4 to $5 \mathrm{~d}$ after a large change in dietary $\mathrm{Mg}$ concentration and Mg source (Van Ravenswaay et al., 1989, 1992). The reason why urinary $\mathrm{Mg}$ output did not reach steady state for cows fed supplemental Mg could not be determined from this study. Spot sampling frequency may have limited our ability to detect steady state (i.e., no sample between $\mathrm{d} 4$ and 7 ). Failing to reach steady state in $7 \mathrm{~d}$ could partly be a consequence of low ruminal solubility of $\mathrm{Mg}$ (Horn and Smith, 1978), which is the rate-limiting step to absorption (Schweigel and Martens, 2000). Because lactating dairy cattle have faster passage rates, larger rumen volumes, and greater $\mathrm{Mg}$ demands compared with sheep or dry cows, the time for soluble $\mathrm{Mg}$ concentrations to reach a maximum may have been longer than the duration of this experiment.

When both $\mathrm{Mg}$ and $\mathrm{K}$ were supplemented, urinary $\mathrm{Mg}$ output did not rapidly decrease such as with the HiK diet, which was contrary to our original hypothesis. Using estimates of Weiss (2004), these cows consumed about $39 \mathrm{~g} / \mathrm{d}$ excess $\mathrm{Mg}$ relative to the dietary $\mathrm{K}$ concentration. The lack of a decrease in urine $\mathrm{Mg}$ output could have been an effect of mass action from the large amount of $\mathrm{Mg}$ consumed, which overwhelmed the antagonist effect of $\mathrm{K}$. 


\section{CONCLUSIONS}

Measuring BW and urinary creatinine was an accurate method for estimating treatment-average excretion of urine, urinary minerals, and $\mathrm{N}$, but lack of fit error was high. Accuracy was poor for many individual observations; future studies using creatinine as a urine marker need to include additional replication to account for both prediction and cow-to-cow variation. Using a fixed rate of creatinine excretion does not include lack of fit variation associated with estimated urine production and affected the statistical interpretation of treatments. Excretion of urinary $\mathrm{Mg}$ reached steady state rapidly after abruptly increasing dietary $\mathrm{K}$, whereas adding supplemental Mg gradually increased excretion over time, and excretion did not reach steady state after $7 \mathrm{~d}$. The different methodology for measuring urine and timeline of $\mathrm{Mg}$ excretion can be used for future balance and $\mathrm{Mg}$ bioavailability studies.

\section{ACKNOWLEDGMENTS}

The authors thank Donna Wyatt of the OARDC Dairy Nutrition Lab for technical assistance and Kevin Miller and the OARDC Krauss Dairy Farm staff for animal care and assistance during the trials. This project was supported by state and federal funds appropriated to the Ohio Agricultural Research and Development Center.

\section{REFERENCES}

AOAC International. 2000. Official Methods of Analysis. Vol. 1 and 2. AOAC International, Gaithersburg, MD.

Blaxter, K., and R. F. McGill. 1956. Magnesium metabolism in cattle. Vet. Rev. Annot. 2:35-55.

Chizzotti, M. L., S. de Campos Valadares Filho, R. F. D. Valadares, F. H. M. Chizzotti, and L. O. Tedeschi. 2008. Determination of creatinine excretion and evaluation of spot urine sampling in Holstein cattle. Livest. Sci. 113:218-225.

de Boer, I. J., M. Smits, H. Mollenhorst, G. Van Duinkerken, and G. Monteny. 2002. Prediction of ammonia emission from dairy barns using feed characteristics part I: Relation between feed characteristics and urinary urea concentration. J. Dairy Sci. 85:3382-3388.

Fach, C. 2015. Ruminal magnesium absorption: Mechanisms, modulation and meaning for assessment of $\mathrm{Mg}$ intake. $\mathrm{PhD}$ dissertation. Freie Universität Berlin, Germany.

Faulkner, M. J., and W. Weiss. 2017. Effect of source of trace minerals in either forage- or by-product-based diets fed to dairy cows: 1. Production and macronutrient digestibility. J. Dairy Sci. 100:5358-5367.
Greene, L. W., G. Schelling, and F. Byers. 1986. Effects of dietary monensin and potassium on apparent absorption of magnesium and other macroelements in sheep. J. Anim. Sci. 63:1960-1967.

Horn, J. P., and R. Smith. 1978. Absorption of magnesium by the young steer. Br. J. Nutr. 40:473-484.

Isaac, R., and W. Johnson. 1985. Elemental analysis of plant tissue by plasma emission spectroscopy: Collaborative study. J. Assoc. Off. Anal. Chem. 68:499.

Jesse, B., J. Thomas, and R. Emery. 1981. Availability of magnesium from magnesium oxide particles of differing sizes and surfaces. J. Dairy Sci. 64:197-205.

Jones, J., B. Wolf, and H. Mills. 1991. Microwave Digestion Using CEM Microwave Digestion System: Plant Analysis Handbook. Micro-Macro, Athens, GA.

NRC. 2001. Nutrient Requirements of Dairy Cattle. 7th rev. ed. Natl. Acad. Press, Washington, DC.

SAS Institute. 2015. SAS/Stat User's Guide. Version 9.4. SAS Institute Inc., Cary, NC.

Schonewille, J. T., H. Everts, S. Jittakhot, and A. Beynen. 2008. Quantitative prediction of magnesium absorption in dairy cows. J. Dairy Sci. 91:271-278.

Schonewille, J. T., A. T. van 't Klooster, H. Wouterse, and A. Beynen. 2000. Time courses of plasma magnesium concentrations and urinary magnesium excretion in cows subjected to acute changes in potassium intake. Vet. Q. 22:136-140.

Schroeder, A., W. Bergen, and R. Merkel. 1990. Estimation of lean body mass, empty body protein and skeletal muscle protein from urinary creatinine excretion in beef steers. J. Anim. Sci. 68(Suppl. 1):311.

Schweigel, M., and H. Martens. 2000. Magnesium transport in the gastrointestinal tract. Front. Biosci. 5:D666-D677.

Shingfield, K., and N. Offer. 1998. Evaluation of the spot urine sampling technique to assess urinary purine derivative excretion in lactating dairy cows. Anim. Sci. 66:557-568.

Storry, J. 1961. Studies on calcium and magnesium in the alimentary tract of sheep I. The distribution of calcium and magnesium in the contents taken from various parts of the alimentary tract. J. Agric. Sci. (Camb.) 57:97-102.

Tebbe, A. W., D. Wyatt, and W. Weiss. 2018. Effects of magnesium source and monensin on nutrient digestibility and mineral balance in lactating dairy cows. J. Dairy Sci. 101:1152-1163.

Valadares, R. F., G. Broderick, S. Valadares Filho, and M. Clayton. 1999. Effect of replacing alfalfa silage with high moisture corn on ruminal protein synthesis estimated from excretion of total purine derivatives. J. Dairy Sci. 82:2686-2696.

Van Ravenswaay, R. O., P. Henry, C. Ammerman, and R. Littell. 1989. Comparison of methods to determine relative bioavailability of magnesium in magnesium oxides for ruminants. J. Dairy Sci. 72:2968-2980.

Van Ravenswaay, R., P. Henry, C. Ammerman, and R. Littell. 1992. Relative bioavailability of magnesium sources for ruminants as measured by urinary magnesium excretion. Anim. Feed Sci. Technol. 39:13-26.

Weiss, W. P. 2004. Macromineral digestion by lactating dairy cows: Factors affecting digestibility of magnesium. J. Dairy Sci. 87:21672171.

Weiss, W. P., N. St-Pierre, and L. Willett. 2009. Varying type of forage, concentration of metabolizable protein, and source of carbohydrate affects nutrient digestibility and production by dairy cows. J. Dairy Sci. 92:5595-5606. 